\title{
INVESTIGATION OF THE PROSPECT OF USING INDEXING CONVENTIONAL UNITS IN THE NATIONAL ECONOMY
}

\author{
Aleksandr Zarichuk \\ Department of finance, banking and business \\ Vinnytsia National Agrarian Univirsity \\ 3 Soniachna str., Vinnytsia, Ukraine, 21008 \\ zsasha111@gmail.com
}

\begin{abstract}
The influence of inflationary and deflationary processes on the determination of the fair value of goods and services is studied in the article. It is established that as a result of changes in the value of money over time, national currencies are not able to effectively perform the function of a measure of value for a long time. In conditions when gold ceased to be the standard of value measurement and became a commodity, in developing countries, the function of the measure of value is taken over by the currencies of countries with more powerful economies. A consequence of this is the strengthening of dollarization and activation of devaluation processes of weaker and open national economies. With the aim of eliminating these problems, determining the fair and real value of goods and services for a long time, it is proposed to introduce a single indexing of a conventional monetary unit. The domestic and foreign experience in implementing the relevant mechanisms has been studied, and recommendations have been made for their testing and implementation within the national economy.
\end{abstract}

Keywords: inflation, measure of value, fair value, dollarization of the economy, indexing conventional monetary unit.

\section{Introduction}

The law of changing the value of money in time asserts that the monetary unit received today is more valuable from a monetary unit in the future. Over time, the value of money is steadily declining by the rate of interest, the value of which depends on the size of borrowing rates in a single market [1]. Also, the monetary unit value is affected by a number of monetary and non-monetary factors - the monetary base, the central bank regulation norms, economic cycles, the general state of development of the national economy, and the like. One manifestation of the concept of changing the value of money over time is inflation, which is manifested by an increase in the general price level and a decrease in the purchasing power of money. As a result, money, being a measure of the value of goods and services, is not a constant unit of such value for a long time. That is, the comparison of the monetary value of one and the same commodity, realized in different time period is incorrect. In connection with the foregoing, in order to determine the objective price of goods and services, to quickly compare their value over different periods of time, there is a need to develop the equivalent of a monetary unit - a fair measure of value protected from inflation and deflation.

For a long time, the standard measure of the value of goods and services was gold. It was at the time of the gold standard that gold did not have its own price, but it was an effective measure of value. With the withdrawal of gold from money circulation, it has become a regular commodity and has its monetary expression [2]. As a result, the volatility of its value has grown substantially. As can be seen from Fig. 1, the value of gold as a commodity even during a short period of time changes significantly, which makes it impossible to use it as an effective measure of value.

In the absence of appropriate alternatives, despite their propensity to depreciate, money combines the functions of a means of payment and a measure of value. In sovereign economies, national currencies are used for this. However, in countries with weak national currencies, whose value for a long time is experiencing significant fluctuations, as an economic measure, economic subjects informally use the more stable currencies of economically developed countries. In Ukraine and CIS countries, such yardstick of value, as a rule, is the US dollar and Euro.

Mass use by legal entities and individuals of these countries to the US dollar as a more effective (in comparison with the national currency) measure of value resulted in the emergence of the euphemism "conventional unit", the value of which corresponds to the official or market rate of the US dollar. 


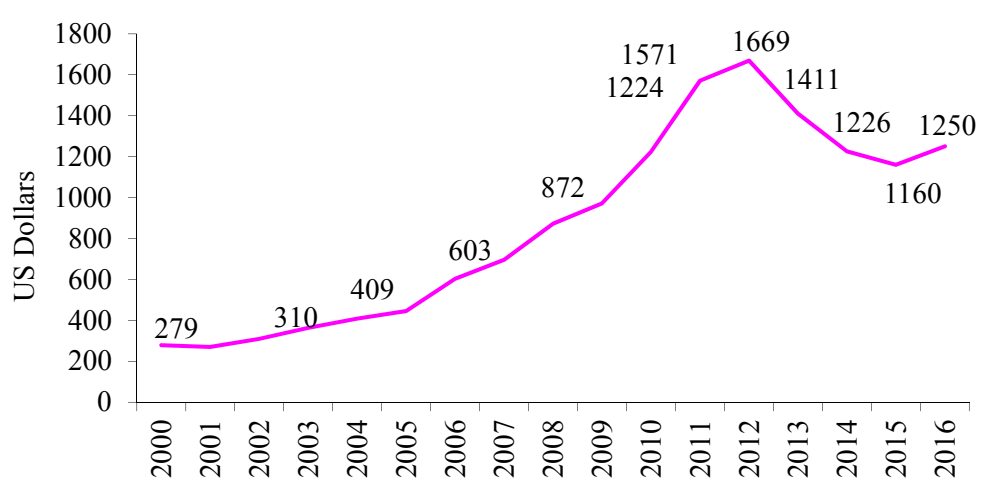

Years

Fig. 1. The price of the Triune ounce of gold during 2000-2016 in US dollars

$$
\text { Source: [3] }
$$

The use of the currencies of other countries with more powerful economies in determining the fair value of goods and services within the national economy is a step that is forced, but inefficient, because the law of changing the value of money in time extends to all currencies without exception. Only the rate of their depreciation differs.

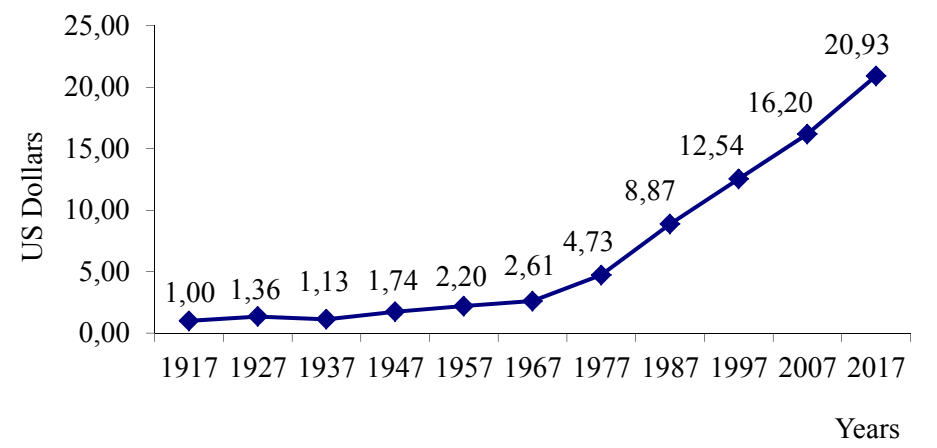

Fig. 2. Chart of purchasing power change of US \$ 1 during the years 1917-2017 Source: [4]

So, if take into account the most popular in Ukraine equivalent of the measure of value - the US dollar, then only in the period from 2000 to 2017 the currency indicated lost $42 \%$ of its purchasing power. In 2000, for 100 US dollars, it was possible to purchase approximately as many goods and services as in 2015 by $\$ 142$. Over the past 100 years, the US dollar has lost more than $95 \%$ of its purchasing power. During the period from 1917 to 2017, the official inflation rate was $1990 \%$, the purchasing power of the US monetary unit declined by more than 20 times. So, 1 US dollar in 1917 is equivalent to 20.93 US dollars in 2017 (Fig. 2).

Taking into account the above, it becomes obvious that the use of the US dollar as a universal equivalent of the cost of goods and services for a long time is inexpedient, and the corresponding practice is erroneous and inefficient.

Thus, the relevance of the search for a monetary equivalent, which most accurately reflects the value of goods and services over a long period of time, is significant.

\section{Analysis of recent research and publications}

In Ukraine, the problem of finding an effective mechanism for establishing the real value of goods and services over a long period of time has been little explored. Thus, in [2], national currencies are investigated as a measure of value and their propensity to distort fair value as a result of inflationary influence is recognized. The author [5] analyzed various practices of inflation adjustment in Ukraine. The negative impact of inflation on the development and effective functioning of the mortgage housing market is proved in. The same author justified the functioning of the indexing 
of the monetary unit. Theoretical developments of these scientists formed the basis of the relevant legislative framework and contributed to the acceleration of their respective practical approbation.

More broadly, the development of effective indexing units for the monetary value of goods and services has been studied in the works of Latin American scholars. Thus, [6] investigates the reasons that led to the introduction of the indexing unit UEFO in Chile. The practical experience of Chile on the introduction of the universal mechanism of indexation of the national monetary unit is studied in [7], and in [3] general recommendations are given for leveling the inflationary influence on the definition of the fair price of goods and services.

These works require not only detailed study, but also rethinking and adaptation in accordance with Ukrainian realities.

\section{The aim and objectives of research}

The aim of the article is studying the prospects of using indexing units in Ukraine as an effective measure of the cost of goods and services for a long time.

To achieve this aim, the following tasks are set:

1. To determine the feasibility of using the US dollar and gold as a fair measure of value in the economies of developing countries.

2. To demonstrate the negative impact of inflationary and deflationary processes on the determination of the fair value of goods and services.

3. To study the positive experience of Chile in implementing the conditional indexing unit UEFO as a reliable monetary equivalent for displaying fair value for a long time. vations.

4. To analyze the relevant Ukrainian experience in the rationalization of inflationary resers

5. To investigate ways to implement the mechanism of indexing a conventional monetary unit in Ukraine.

\section{Materials and methods of research}

In this article, an attempt will be made to find out the best ways to determine the fair value of goods and services by using universal indexing of conventional units. At the same time, when studying the object of research, methods of stochastic, graphic, retrospective analysis of statistical data and comparisons will be used, on the basis of which relevant proposals and recommendations will be developed

\section{Research results}

The first attempt to create a universal equivalent of the cost of goods and services, which in the most convenient way would most accurately perform the function of a measure of value and did not lose purchasing power for a long time, was the introduction of a special conventional unit of UEFO (UF - Unidad de Fomento) in Chile. Since 1967, UEFO is a conventional unit of accounting, changing its value depending on the level of inflation in the country.

The use of the UEFO conditional currency in Chile has two important functions. First, it is the expression of the cost of goods and services, the purified influence of the inflationary factor. Secondly, UEFO is an effective reference point for real and not nominal changes in prices and prices in the national economy.

During 1975-2016, the UEFO rate, nominated in pesos, increased 278 times - from 94.7 to 23347 pesos (Fig. 3). Accordingly, the growth rate of UEFO clearly demonstrates the depreciation of the value of the national monetary unit as a result of the cumulative impact of inflationary factors. Thus, the course of the UEFO, being cleared of the influence of inflation, demonstrates the real purchasing power of the national currency.

Originally, UEFO was designed to protect savings from the loss of their purchasing power due to the impact of inflation. The use of UEFO enabled financial institutions not only to protect depositors' savings from a decrease in the purchasing power of the national currency, but also to guarantee the payment of real (and not nominal) profits. This is encouraged private households to make long-term investments of their own savings in various financial instruments nominated in 
UEFO, which had a tangible positive effect in the development of the national economy by mobilizing domestic investment potential.

It is the nomination of relevant savings in UEFO, their indexing on the level of inflation for the relevant period, accruals and capitalization of income in this conditional unit played a decisive role in the formation and development of Chile's national funded pension system. Since the involved pension savings are automatically indexed to the inflation rate, the owners of the respective accounts were protected from the loss of their savings in purchasing power, which in turn stimulated the growth of the corresponding deductions. As a result, the assets of accumulative pension funds at the beginning of 2017 exceeded $70 \%$ of Chile's GDP, while pension savings in some years accounted for up to $65 \%$ of the national capital market and provided $60 \%$ of housing finance.

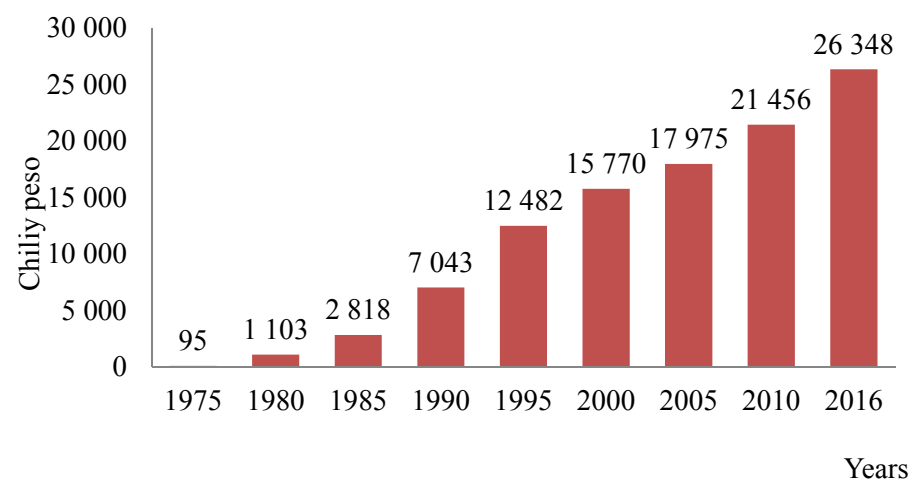

Fig. 3. The cost of the UEFO, denominated in peso during 1975-2016 Source: [6]

The property of the conventional monetary unit UEFO to maintain its purchasing power for a long time contributed to the popularization of this tool in Chile. Gradually, the use of UEFO was extended to all types of bank loans and private investments. Mostly in UEFO, construction costs, real estate and mortgage costs and rent of housing are nominated. Most public finances are also denominated in the UEFO. Thus, this conditional monetary unit is used to determine the maximum taxable income, the base for calculating contributions for social insurance, pension funds and unemployment insurance, and for determining the minimum wage and pension [7].

The practice of Chile showed that the use of the mechanism of a conventional monetary unit indexed for inflation is an effective unit of the value measurement, its use eliminates the need for a constant adjustment of nominal and real prices, makes it possible to obtain a fair value of goods and services at each time, cleared of influence inflation factors. In this sense, UEFO is an effective measure of value, unlike conventional currencies, it always retains its purchasing power.

In addition, the widespread use of indexing a conventional unit as a measure of value in the national economy while preserving the national currency as a means of payment allowed the government of Chile to implement a simple and understandable mechanism for determining the real value of goods and services, taking into account the time factor, effectively and automatically indexing fiscal payments and social benefits, mobilize domestic private investment and stimulate the economic development of the national economy, in parallel reducing its dollarization level.

In Ukraine, too, there is a practice of using mechanisms to compensate for the inflationary impact on the purchasing power of the national currency. Thus, for "correction of the negative impact of inflation on cash, an inflationary corrector is applied" [5]. An inflationary corrector as well as other mechanisms for adjusting the valuation of assets, liabilities and cash collateral are used to index the monetary incomes of citizens, to carry out land valuation, to revalue fixed assets, to determine the amount of financing of state targeted programs, to determine the post-privatization obligations of investors, to evaluate investment projects, insurance, investment of savings of nonstate pension funds and the like.

However, the use of an inflationary corrector, like other mechanisms for leveling inflationary processes in Ukraine, has a fragmentary nature and is applied locally. In addition, their ef- 
fective use is complicated by the deforming influence of a number of regulatory and legal acts, corrective coefficients are introduced that distort fair indexation in certain areas (land valuation, depreciation calculation, book value of assets, cash security, pension payments, etc.). This use of correction factors in the implementation of indexation leads to an even greater complication in determining the fair value of goods and services. Accordingly, the model of fragmentary application of indexation of inflationary influence is complicated by administrative regulation in the conditions of functioning of a market economy that is unviable in Ukraine. Wide use in informal calculations and in determining the fair value of goods and services to the US dollar as a measure of value is a confirmation. Therefore, in order to implement an effective mechanism to compensate for the inflationary impact on socio-economic processes and to determine the fair value of goods and services over a long period, it is advisable in Ukraine to carefully study the experience of Chile in implementing the UEFO settlement unit and the prospects for its implementation in Ukraine.

Now, domestic legislation provides for the application of an inflationary clause by applying indexing conditional monetary units in determining debt under a mortgage debt. Thus, in accordance with the Law of Ukraine "On Mortgage Lending, Operations with Consolidated Mortgage Debt and Mortgage Certificates," an inflationary clause in order to maintain the real value of monetary claims and lender's income and to account for the obligations of debtors under contracts for a mortgage debt can use indexing conditional units [8]. The Law of Ukraine "On Financial and Credit Mechanisms and Property Management in the Construction of Housing and Real Estate Operations" also provides for the use of indexing conditional units for indexation of borrower's payments on a mortgage [9].

In Ukraine, practical experience in realizing the mechanism of functioning of indexing a unit of account similar to the Chilean UEFO is implemented by the Arcada bank in the implementation of active-passive operations by using indexing a conventional OdIn.

So, in accordance with the Law of Ukraine "On conducting an experiment in housing construction on the basis of the holding company" Kyivmiskbud ", in order to protect the funds of depositors of the authorized bank, the accounting of the relevant attracted resources was carried out in conditional indexing OdIn. OdIn is defined by the authorized bank and determines on the basis of its own methodology, taking into account the inflation index, the price index of producers of industrial products, the price index for construction and installation works and a friend their factors at the discretion of the bank, which affect the determination of the value of the mortgage obligation [10].

After the entry of the Law of Ukraine into force, OdIn rate is calculated according to the following formula:

$$
\mathrm{K}_{\mathrm{i}}^{\mathrm{k}}=\mathrm{K}_{\mathrm{i}}^{\mathrm{n}} \cdot \mathrm{I}_{\mathrm{i}} / 100
$$

where $\mathrm{K}_{\mathrm{i}}^{\mathrm{k}}$ - the OdIn rate at the end of the $\mathrm{i}$-th calculation period; $\mathrm{K}_{\mathrm{i}}^{\mathrm{n}}$ - the OdIn rate at the begini ning of the $\mathrm{i}$-th accounting period; $\mathrm{I}_{\mathrm{i}}$ - inflation index according to Goskomstat data in the month preceding the accounting period.

Thus, the OdIn rate in the national currency accurately reflected the inflation index, therefore, the assets and liabilities of the bank nominated in OdIn allowed to preserve the real (and not nominal) value of both attracted deposits and issued loans. In this aspect, OdIn was an analogue of the Chilean UEFO, but on a much smaller scale.

Providing real income and protecting depositors' savings from inflation by taking into account monetary obligations in indexing conventional units allowed the authorized bank to increase raising funds on a long-term basis. The increase in the receipt of "long" money depositors, in turn, provided an opportunity to significantly increase the duration of mortgage lending. Thus, the practical approbation of the mechanism of indexing a conventional unit, which protects depositors' funds from devaluation of the national currency, has allowed increasing the attraction of the population's funds and forming a long-term credit resource.

According to the honored economist of Ukraine, Chairman of the Board of the "Arcada" bank K. Palyvoda "... fixing of the interest rate when carrying out active-passive operations by a 
commercial bank and directly applying a floating interest rate effective in a stable low inflation situation. If the inflation rate changes unpredictably and the amplitude of these changes can exceed $5 \%$ per annum, then the application of the floating interest rate mechanism becomes very difficult, and banks that use fixed interest rates start to incur losses". Therefore, in order to minimize interest risk when performing active/passive operations in conditions of sharp inflationary fluctuations, it is advisable for banks to abandon the use of fixed interest rates in favor of using indexing conditional units of account. This will allow them to hedge interest risks and synchronize the timing of incoming and outgoing cash flows.

For example, "Arcada" bank, having formed a long-term credit resource, nominated in OdIn, was able to provide mortgage loans, also nominated in one, which significantly increased the duration of mortgage lending - up to 30 years, while avoiding the risk of interest rate changes and inconsistencies in value assets and liabilities by maturity. At the same time, long-term liabilities of borrowers nominated in OdIn are divided by the number of planned payments. As a result, the borrower knows the planned amount of payment in one and its current rate, as a result, can independently determine the amount of payment in the hryvnia. And although in the national currency the repayment of obligations is uneven, the repayment of the real value of the debt occurs in equal parts.

Practical approbation of the indexing of the conventional unit OdIn demonstrated a number of advantages for the bank and its clients. These include:

- automatic indexation of deposits and loans;

- receipt by investors of real and not nominal interest income on the placed capital;

- synchronization of cash flows;

- minimization of interest rate risk when the bank performs active-passive operations;

- creation of conditions for the formation of long-term credit resources;

- consistency of active-passive transactions in terms of time and cost;

- systemic reduction of operational risks, improvement of liquidity and financial stability of the credit institution.

Also, the practical application of indexing conventional units in long-term lending has revealed a number of problems in comparison with the usual lending in the national currency. So, with an increase in inflation, the lender faces risks of untimely administration of payments. They are caused by an unpredictable increase in borrowers' liabilities denominated in indexing conventional units as a result of the indexation. The growth of inflation causes a proportional increase in borrowers' expenses for repayment of indexed debts and payment of the corresponding interest, increases the burden on household budgets and may cause arrears.

Now in Ukraine there is no practice of full-value indexation of incomes of citizens in accordance with the inflation level. Accordingly, the growth of borrowers' expenses on received loans, denominated in indexing conventional units and indexed for inflation, not supported by the corresponding indexation of their incomes and increases the share of total household expenditures on servicing credit debt. A significant increase in the rate of inflation can cause a critical increase in the credit debt of individual households, in which their incomes cover the corresponding expenses for servicing liabilities denominated in conventional monetary units. This negatively affects the quality of the loan portfolio and increases the credit risk of the bank.

The growing risk of overdue debt on indexed assets threatens timely and full implementation of the bank's obligations to index the corresponding liabilities, thereby negatively affecting the financial stability of the credit institution. Accordingly, when using indexing conditional units of account, there is a need for additional balancing of active-passive transactions. So, in 2015 , in order to avoid the need to index the full extent of borrowers' liabilities to the inflation rate, which reached $43 \%$ in relation to the previous year, a decision was made to introduce a limit value for the consumer price index when calculating the OdIn rate. Thus, the administrative decision limited the maximum allowable value of OdIn rate, which led to its lagging behind the actual rate of inflation during 2015-2016 (Fig. 4). This made it possible to reduce the risk of non-payments for loans, nominated in OdIn, to limit the costs of servicing liabilities and to predict the corresponding costs for their servicing. 


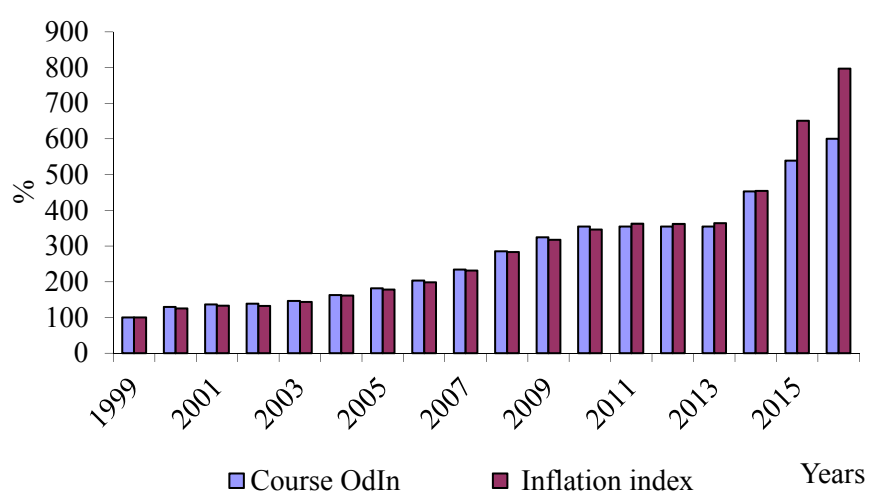

Fig. 4. The growth rate of the OdIn rate and the inflation index in Ukraine during 1999-2016

Since 1999, practical approbation of the indexing of the OdIn conventional unit has demonstrated the viability of this mechanism and its feasibility in the formation of a long-term resource base of financial institutions. At the same time, it is found that the use of indexing conventional units only in the sphere of financial and credit operations leads to an increase in the borrowers' expenses for servicing the corresponding credit debt and increases the credit risks of lenders.

Now, the broader use of indexing conventional units in the national economy is provided for by current legislation. So, according to the Law of Ukraine "On Mortgage Lending, Operations with Consolidated Mortgage Debt and Mortgage Certificates," an inflation warning with the help of indexing conventional units can only be used for mortgage lending with a view to accounting for liabilities. In addition, the rules for establishing the value of indexing conditional monetary units and, accordingly, the methods of indexing credit obligations of debtors are determined separately by each lender [8]. The right of each lender to independently establish the conditions for indexation of credit obligations not only complicates the perception of the instrument of indexing conventional units by consumers, but can also become a source of potential abuse and manipulation of the conditions for indexing assets on the part of the lender, contributes to the production of various types and types of indexing conditional monetary units. This rule of law does not promote the unification and full-fledged indexation of credit obligations, leading to only a local application of the instrument of indexing conventional units.

Fragmentary use of indexing conventional units only in the sphere of financial and credit relations, apart from certain positive results, is not able to promote their use as an effective equivalent of a measure of value, a mechanism for fair indexation of incomes and expenditures of both individuals and legal entities, and the consolidated state budget.

Accordingly, in order to unify the implementation of the instrument of indexing conventional units, it is necessary to abandon the practice of unauthorized setting by each individual lender of their own methods and types of indexing conditional units of accounting, to legislatively fix the order of formation of such unit value on the basis of inflation index for the previous period, and indexing credit debt by accounting of respective obligations based on the value of a single conventional monetary unit. The next step in popularization of indexing conventional units is the spread of their use beyond the banking system, as a full measure of the cost of goods and services, which requires the development and adoption of appropriate legislation.

Chile's experience demonstrates a positive correlation between the growth of the potential use of conditional indexing units and the increase in the scope of its application in the national economy. Thus, the practice of maximum use of UEFO in the sectors of the national economy not only helped create an effective mechanism for determining the fair measure of the cost of goods and services for a long time, but also discouraged the use of the US dollar as a universal measure of value and means of payment area.

Accordingly, in Ukraine, in order to unify the process of indexing inflation, determining the fair value of goods and services over a long period of time, ousting other countries' currencies, increasing the use of the hryvnia as a means of payment, and finally, local use of the inflationary 
corrector and other disparate and uncoordinated mechanisms of inflationary revaluation of assets and liabilities. But, it is advisable to focus on the introduction of a single conditional indexing of the monetary unit, similar to the Chilean UEFO, and legislatively fix the procedure for indexing exclusively through the mechanism of this conditional monetary unit. At the same time it will be useful to take into account the practical testing in Ukraine by indexing the OdIn. The implementation of these steps will allow to neutralize the negative impact of inflation on the objective determination of the cost of goods and services within the national economy, to promote the establishment of fair prices for a long period of time.

\section{Discussion of research results}

In this study, the problem of distortion of the real value of goods and services as a result of inflationary impact is analyzed. The recommendations on the introduction of a universal system of automatic indexation of relevant values by introducing a mechanism for indexing conventional monetary units are given. The introduction of this mechanism will make it possible to use indexing conditional monetary units as a fair measure of value, which will positively affect the development of the national economy and its agents, primarily in such areas of the national economy as construction, mortgage lending, finance, administration of taxes and fees and social payments.

\section{Conclusions}

As a result of the researches it is established:

1. The use of the US dollar in determining the fair value of goods and services in developing countries is false given its propensity for depreciation due to inflation.

2. It is proved that gold in modern conditions can't perform the function of a measure of value, because as a result of the abolition of the policy of the gold standard, it became a commodity and its value is fairly volatile.

3. It is recognized the relevance of the search for new mechanisms for determining fair value by introducing new mechanisms for indexing inflationary and deflationary processes.

4. It is established that the most optimal mechanism for determining fair value is the use of broad indexation of the value of goods and services using indexing conditional monetary units similar to the Chilean UEFO or Ukrainian one.

5. Practical recommendations for the implementation of the mechanism of indexing a monm etary unit in Ukraine are developed.

\section{References}

[1] Mamaluj, O. O., Grycenko, O. A., Gryshhenko, L. V., Darnopyh, G. Yu. (2003). Osnovy ekonomichnoyi teoriyi. Kyiv: Yurinkom Inter, 480.

[2] Food and Agriculture Organization (2015). Report of the expert consultation Meeting on Food losses and Waste Reduction in the near east Region. Available at: http://www.fao.org/

[3] Food and Agriculture Organization (2016) Global food losses and food waste - extent, causes and prevention. Rome, 37. Available at: http://www.fao.org/docrep/014/mb060e/mb060e.pdf

[4] Regional Overview of Food Insecurity Near East and North Africa (2015). 32. Available at: www.fao.org/3/a-i4644e

[5] Food, beverage and agriculture industry in sights. Available at: http://www.gecapital.com.au/ knowledge-hub/2014/food-and-beverage-industry/food-beverage-and-agriculture-industry-insights.pdf

[6] Kozak, Yu. G., Logvynova, N. S., Rzhepishevsko, K. I. (2005). Osnovy mizhnarodnoyi torgivli. Kyiv: Centr navchalnoyi literatury, 656.

[7] Novyczkyj, V. Ye. (2003). Mizhnarodna ekonomichna diyalnist Ukrayiny. Kyiv: KNEU, 948.

[8] Oficijnyj sajt OON. Available at: http://www.un.org

[9] World trade report 2014 (2014). Available at: https://www.wto.org/english/res_e/booksp_e/ world_trade_report14_e.pdf

[10] United nations, department of economic and social affairs - Population division, 2015 (2015). Available at: http://www.un.org/en/development/desa/population/ 